\title{
PALEOMAGNETISMO DOS CARBONATOS DE CAPA DO CRÁTON AMAZÔNICO (BRASIL): IMPLICAÇÕES PARA AS GLACIAÇÕES DO NEOPROTEROZÓICO
}

\author{
Eric Claude Font \\ Orientador: Dr. Ricardo Ivan Ferreira da Trindade (IAG-USP) \\ 203 p. - Tese (Doutorado) - Defesa 22.11.2005
}

\begin{abstract}
RESUMO. No Neoproterozóico, a Terra pode ter passado por vários eventos de glaciação, sugeridos pela presença de sedimentos glaciais sistematicamente capeados por seqüências carbonáticas (cap carbonates) em diversos continentes. Estudos paleomagnéticos indicam que algumas destas sucessões sedimentares foram depositadas em baixas latitudes, levando a crer que as calotas de gelo cobriram toda a superfície do planeta. Esta hipótese, conhecida como "Terra Bola de Neve" (Snowbal/ Earth ), evoca as mudanças climáticas mais extremas da história da Terra, as quais poderiam ter levado a diversificação de formas de vida que deram início ao Cambriano. Os estudos geocronológicos e isotópicos obtidos nos últimos anos identificam pelo menos três eventos glaciais ao longo do Neoproterozóico. Porém, a quantidade de dados paleomagnéticos disponíveis é insuficiente para testar o caráter global destas glaciações. Ainda, de acordo com o modelo Snowbal/ Earth, 0 degelo teria ocorrido de forma extremamente rápida. Faltam entretanto vínculos temporais para o período inicial de deposição dos carbonatos de capa. 0 meio de deposição e as condições redoxes nas quais estas rochas se depositaram são igualmente pouco estudados. As respostas para estas questões requerem uma quantidade maior de dados paleomagnéticos e geoquímicos, atualmente limitados a alguns continentes. Os dados paleomagnéticos obtidos nos carbonatos Neoproterozóicos do Grupo Araras, Mato Grosso, permitiram identificar duas componentes magnéticas distintas. Os calcários betuminosos da Formação Guia registraram uma magnetização secundária adquirida durante o fim da orogênese Brasiliana ( $520 \mathrm{Ma}$ ). Os dolomitos subjacentes da Formação Mirassol d'Oeste, que capeiam os diamictitos da Formação Puga ( $\sim 635 \mathrm{Ma}$ ), apresentam características de uma magnetização primária com a presença de várias inversões do campo magnético. 0 estudo de mineralogia magnética destas rochas identifica hematita e magnetita, todas de origem détritica, como portadores da magnetização. Estes resultados indicam uma deposição em baixas latitudes $\left( \pm 22^{\circ}\right)$ para os sedimentos glaciais e permitem determinar a posição paleogeográfica do cráton Amazônico durante este período. Os dados quimio- e magnetoestratigráficos comprovam o caráter primário dos dolomitos e indicam que essas rochas precipitaram num ambiente raso, anóxico possivelmente influenciado pela atividade de bactérias sulfato-redutoras. A presença de varias inversões do campo magnético sugere que a deposição levou mais de 105 anos, tempo consideravelmente maior do que previsto pelo modelo Snowbal/ Earth. Propomos então um modelo alternativo, de precipitação da dolomita primária influenciado pela atividade bacteriana, dentro de um meio anóxico e discutimos a evolução paleogeográfica das margens continentais após um dos eventos glaciais di Neoproterozóico.
\end{abstract}

ABSTRACT. During Neoproterozoic times the Earth may have experimented several glacial events indicated by the presence of glacial deposits in several continents which are systematically capped by carbonates (cap carbonates). Paleomagnetic studies indicate that some of these sequences have been deposited in low latitudes, leading to the idea that ice had covered the entire planet at these times. This hypothesis, the so-called snowball Earth hypothesis, evocates the most extreme climatic changes of the history of the planet which paved the way for the diversification of life species at the beginning of Cambrian times. Geochronologic and isotopic data of these rocks identify at least three glacial events during Neoproterozoic times. However, the available paleomagnetic data base is still insufficient to test the global extension of these deposits. According to the snowball Earth hypothesis, the transition from ice-house to green-house conditions must have been abrupt and rapid but this assumption remains speculative. The geographic and geochemical conditions of the depositional environment of these rocks, especially of the basal dolomitic sequence which could be used to test such scenarios, are also poorly documented. More paleomagnetic and geochemical data on well-preserved post-glacial Neoproterozoic successions are needed to properly address these issues. Paleomagnetic data obtained on the neoproterozoic carbonates of the Araras Group, Mato Grosso, revealed two different magnetic components. The bituminous limestones of the Guia Formation record a secondary magnetization acquired during the end of the Brasiliana orogenesis $(\sim 520 \mathrm{Ma})$ and give a paleomagnetic pole at Lat $=-82,6^{\circ}$ et $\mathrm{Long}=292,6^{\circ}(\mathrm{N}=13, \mathrm{A95}=7,8, \mathrm{~K}=29,1)$. The basal dolostones of the Mirassol d'Oeste Formation, capping the glacial deposits of the Puga Formation ( $\sim 635 \mathrm{Ma}$ ), present primary magnetic signatures characterized by the occurrence of several geomagnetic reversals. The magnetic mineralogy study of these rocks identifies hematite and magnetite, both of detrital origin, as carriers of the magnetization. These results gives a paleomagnetic pole at Lat $=33,6^{\circ}$ and Long $=326,9^{\circ}(\mathrm{N}=16$ sites, $A 95=7,0, \mathrm{~K}=28,9)$ and indicate a low latitude deposition $\left( \pm 22^{\circ}\right)$ for the glacial deposits and constrain the paleogeographic position of the Amazon craton at these times. Chemo- and magnetostratigraphic data confirm the primary nature of the dolostones and indicate that they have been deposited in a shallow and anoxic environment, possibly influenced by sulfate-reducing bacterial activity. Presence of several geomagnetic reversals in the Mirassol d'Oeste dolostones suggests a minimum interval of 105 years for the deposition of the cap dolostones. We suggest a microbially-mediated model for the precipitation of the primary dolomite, in an anoxic environment. In addition we discuss the paleogeographic context of neoproterozoic continental margins in the aftermath of a Neoproterozoic glacial event. 